\title{
Functions of Industrial Cement Components with their Benefits and Limitations
}

\author{
Vivek Sharma \\ $\mathrm{Ph} . \mathrm{D}$. Scholar, Manipal University Jaipur, Jaipur \\ E-mail: mailtovivek3@gmail.com
}

Abstract

Solid industry expect a fundamental activity in the unforeseen development and improvement of India. It is limiting substance required while building something. In this paper we are looking at changed kinds of fixings and the extent of these fixings that are be used in Portland concrete. In this paper we moreover discussing the convenience of these fixing.

\section{INTRODUCTION}

Silicate concrete is a standard Portland concrete, in which the shade of concrete delivered utilizing it resembles trademark rocks on the British island of Portland. For the Portland concrete, the rough material contain 3 basic fragment that is calcium oxide(approx. 60\%), silicon dioxide $(22 \%)$ and alumina(10\%). The calcium oxide starts from limestone, while silica and alumina begin from shale, mud and bauxite. The unrefined materials moreover contain iron oxide, magnesia, calcium sulfate, etc. 


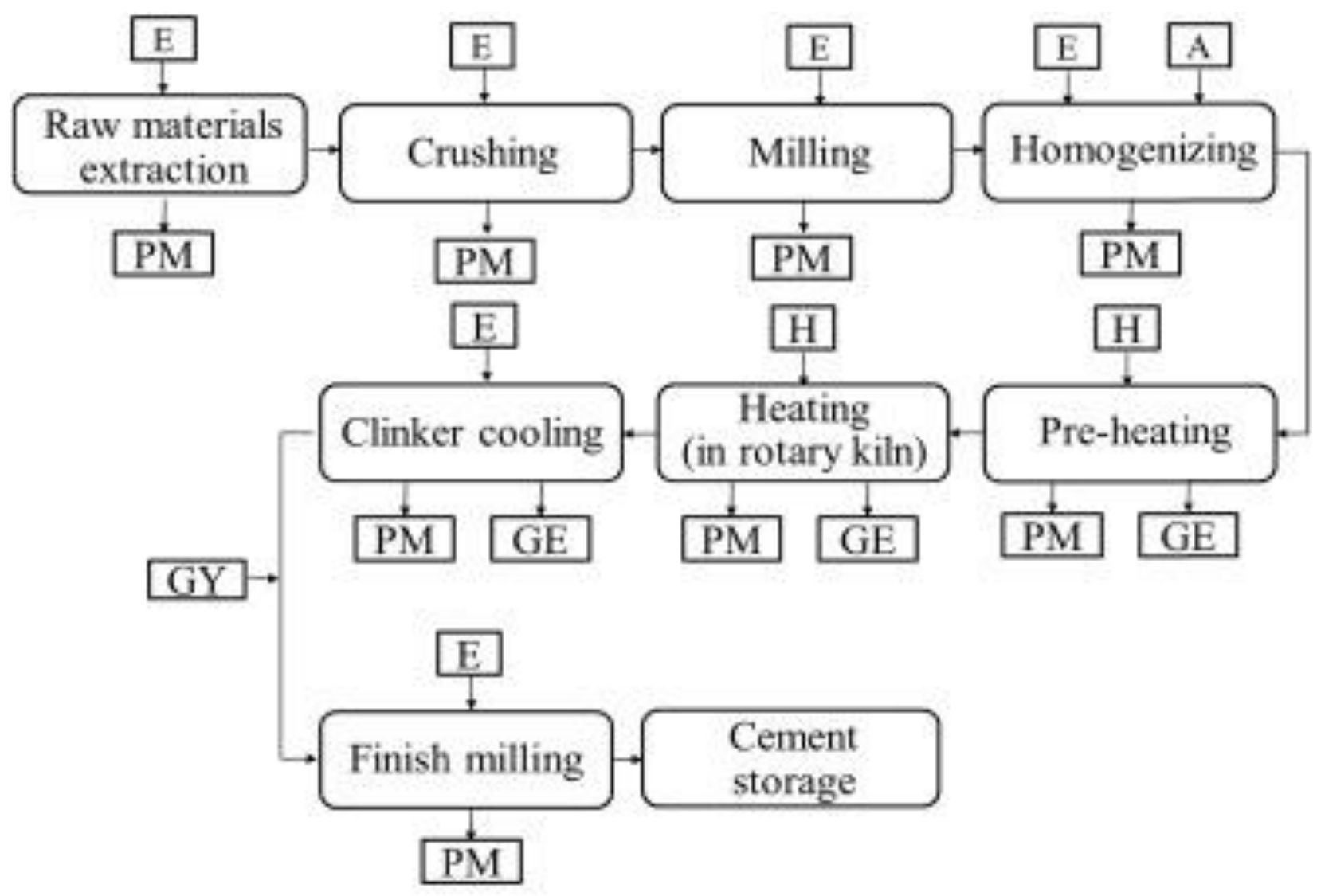

Fig 1: Portland cement

\section{FUNCTIONS OF CEMENT INGREDIENTS}

Every ingredient imparts various properties to the cement. The proper ratio of various ingredients of cement produces the good quality of cement

\section{(1) Lime (CaO):}

It is most significant ingredient of cement and its ratio has to wisely maintain. The cement comprises 62 to $67 \%$ of lime in it. It is acquired by limestone, chalk, shale and so on. The suitable amount of lime in cement forms the silicates and aluminates of calcium. The deficiency 
of lime decreases the strength of cement also decreases the setting time of cement and access quantity of lime in cement becomes unreliable as well as development and crumbling of cement.

TABLE 1:

RANGE OF CEMENT INGREDIENTS

\begin{tabular}{|c|c|c|}
\hline Ingredient & Per cent & Range \\
\hline Lime & $(\mathrm{CaO}) \ldots \ldots \ldots \ldots \ldots \ldots, 62$ & 62 to 67 \\
\hline Silica & $\left(\mathrm{SiO}_{2}\right) \ldots \ldots \ldots \ldots \ldots \ldots 22$ & 17 to 25 \\
\hline Alumina & $\left(\mathrm{Al}_{2} \mathrm{O}_{3}\right) \ldots \ldots \ldots \ldots \ldots \ldots$ & 3 to 8 \\
\hline Calcium sulphate. & $\left(\mathrm{CaSO}_{4}\right) \ldots \ldots \ldots \ldots \ldots \ldots$ & 3 to 4 \\
\hline Iron oxide & $\left(\mathrm{Fe}_{2} \mathrm{O}_{3}\right) \ldots \ldots \ldots \ldots \ldots \ldots \ldots$ & 3 to 4 \\
\hline Magnesia & $(\mathrm{MgO}) \ldots \ldots \ldots \ldots \ldots \ldots, 2$ & 1 to 3 \\
\hline Sulphur & (S) $\ldots \ldots \ldots \ldots \ldots \ldots \ldots, 1$ & 1 to 3 \\
\hline \multirow[t]{2}{*}{ Alkalies } & $\ldots \ldots \ldots \ldots \ldots \ldots, 1$ & 0.2 to 1 \\
\hline & Total. . . . . . . . . 100 & \\
\hline
\end{tabular}

Proportion of Cement Ingredients

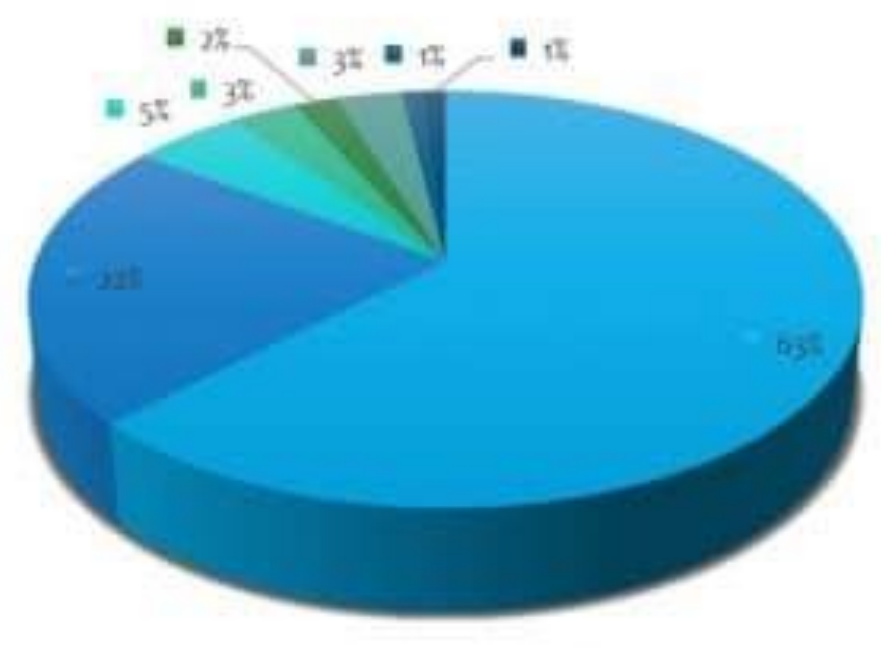

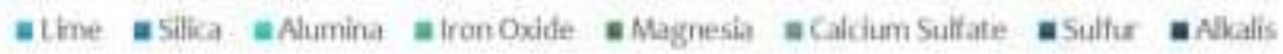

Fig 2: cement ingredients 


\section{(2) Silica $\left(\mathrm{SiO}_{2}\right)$ :}

It is also the main ingredient of cement which is about 17 to $25 \%$.

(3) Alumina $\left(\mathrm{Al}_{2} \mathrm{O}_{3}\right)$ :

This ingredient imparts quick setting property to the cement.

\section{(4) Calcium Sulphate (CaSO 4$)$ :}

It is present in the form of gypsum in the cement and found composed with limestone.

\section{(5) Iron Oxide $\left(\mathrm{Fe}_{2} \mathrm{O}_{3}\right)$ :}

The property of this ingredient imparts colour, hardness and strength to the cement.

\section{(6) Magnesia (MgO):}

Excess quantity makes the cement unsound and also reduces the strength of the cement .

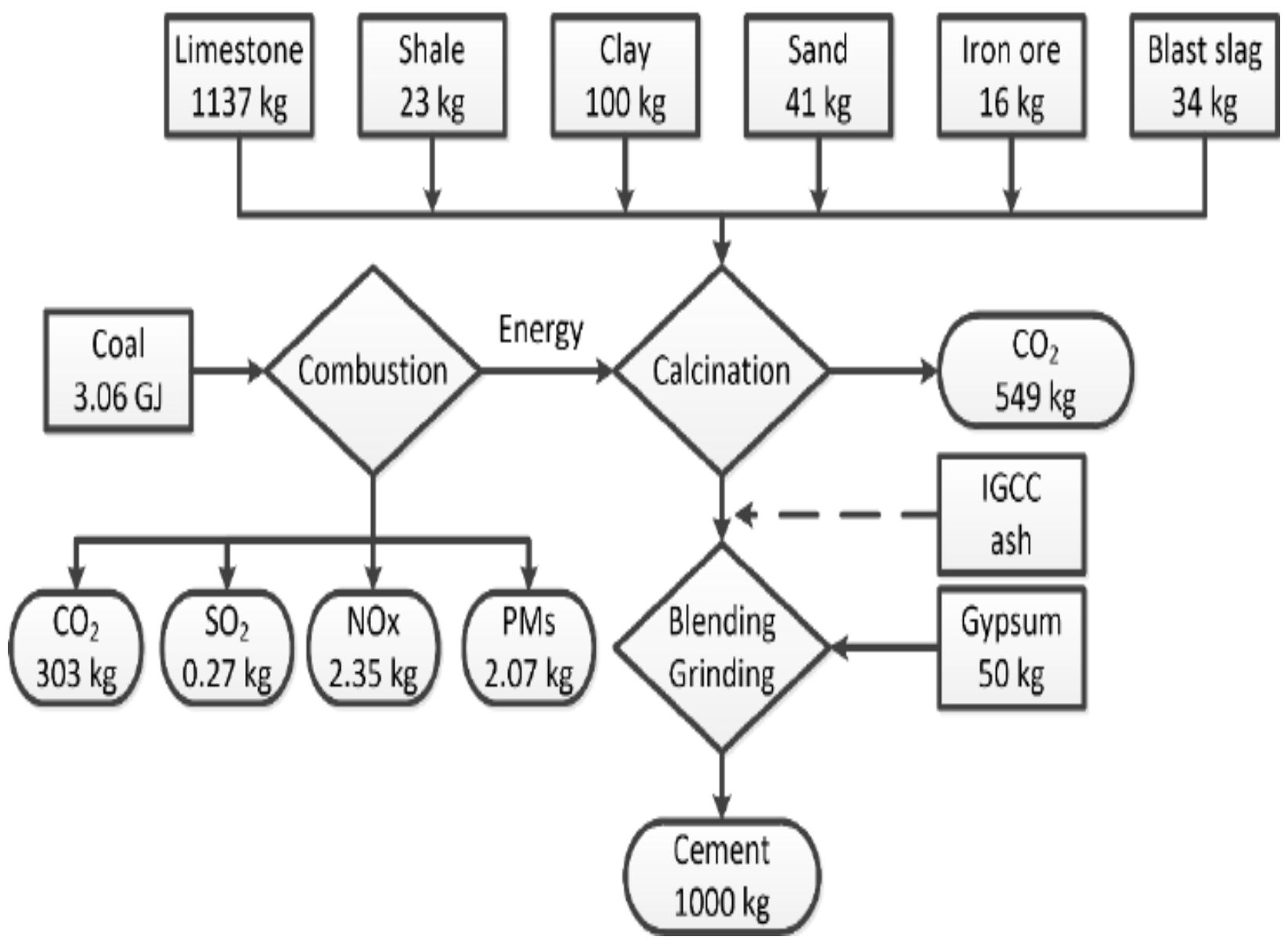

Fig 3: Conventional Portland cement production 


\section{CONCLUSION}

In this paper, we have discussed about the Portland cement and function of ingredients used in manufacturing the Portland cement. In this paper we have also calculated the ratio of various cement ingredients with its properties. The possible reasons for variation in chemical compositions and their consequences have been discussed.

\section{REFERENCES}

[1] C. M. Hanson, "Concrete: the advanced industrial material of the 21st century," Metallurgical \& Materials Transactions A, vol. 26, pp. 1321-1341, 1995.

[2] M. Bediako, S. K. Y. Gawu, and A. A. Adjaottor, "Suitability of some Ghanaian mineral admixtures for masonry mortar formulation," Construction and Building Materials, vol. 29, pp.

667-671, 2012.

[3] S. H. Kosmatka, B. Kerkhoff, and W. C. Panarese, Design and Control of Concrete Mixtures, Portland Cement Association,Skokie, Ill, USA, 14th edition, 2002.

[4] M. S. Mamlouk and J. P. Zaniewski, Materials for Civil andConstruction Engineers, Prentice Hall, Upper Saddle River, NJ,USA, 2006.

[5] T. Punmatharith, M. Rachakornkij, A. Imyim, and M.Wecharatana, "Co-processing of grinding sludge as alternative raw material in portland cement clinker production," Journal of Applied Sciences, vol. 10, no. 15, pp. 1525-1535, 2010.

[6] D. N. Huntzinger and T. D. Eatmon, "A life-cycle assessment of Portland cement manufacturing: comparing the traditional process with alternative technologies," Journal of Cleaner Production, vol. 17, no. 7, pp. 668-675, 2009.

[7] F. M. Lea, The Chemistry of Cement and Concrete, Arnold Publishers, London, UK, 3rd edition, 1970.

[8] J. F. Young, S.Mindess, R. J. Gray, andA. Bentur,TheScience andTechnology of Civil Engineering Materials, Prentice-Hall, Upper Saddle River, NJ, USA, 1998.

[9] H. F. W. Taylor, Cement Chemistry, Thomas Telford, London,UK, 2nd edition, 1997.

[10] S. H. Kosmatka and M. L. Wilson, Design and Control of Concrete Mixtures, Portland Cement Association, Stokie, Ill, USA, 2011.

[11] V. Sata, C. Jaturapitakkul, and K. Kiattikomol, "Influence of pozzolan from various by-product materials on mechanical properties of high-strength concrete," Construction and BuildingMaterials, vol. 21, no. 7, pp. 1589-1598, 2007.

[12] A. Neville, Neville on Concrete, ACI, Farmington Hills, Mich, USA, 2003.

[13] R. Fernandez, F. Martirena, and K. L. Scrivener, "The origin of the pozzolanic activity of calcined clay minerals: a comparison between kaolinite, illite and montmorillonite," Cement and

Concrete Research, vol. 41, no. 1, pp. 113-122, 2011.

[14] K. Ganesan, K. Rajagopal, and K. Thangavel, "Evaluation of bagasse ash as supplementary cementitious material," Cement and Concrete Composites, vol. 29, no. 6, pp. 515-524, 2007.

[15] S. Sinthaworn and P. Nimityongskul, "Quick monitoring of pozzolanic reactivity of waste ashes," Waste Management, vol.29, no. 5, pp. 1526-1531, 2009. 
[16] J. J. Brooks,M. A.M. Johari, andM.Mazloom, "Effect of admixtures on the setting times of highstrength concrete," Cement and Concrete Composites, vol. 22, no. 4, pp. 293-301, 2000.

[17] X. Fu, Z.Wang,W. Tao et al., "Studies on blended cement with a large amount of fly ash," Cement and Concrete Research, vol. 32,no. 7, pp. 1153-1159, 2002.

[18] E.-H. Kadri, S. Kenai, K. Ezziane, R. Siddique, and G. De Schutter, "Influence of metakaolin and silica fume on the heat of hydration and compressive strength development of mortar," Applied Clay Science, vol. 53, no. 4, pp. 704-708, 2011. 